\title{
BIOCHEMICAL AND ISOENZYME ANALYSES OF ELEPHANT GRASS, Pennisetum purpureum (SCHUM) VARIETIES
}

\author{
E.E.BACH ${ }^{1}$; V.B.G. ALCÂNTARA ${ }^{2,3}$; P.B. ALCÂNTARA ${ }^{2,3}$; E.A. VEASEY ${ }^{2,3}$ \\ 'Seģão de Bioqutmica Fǘopatológica - IB, C.P. 7119, CEP: 01064-970, São Paulo, SP \\ ${ }^{2}$ Seção de Agronomia de Plantas Forrageiras - IZ, C.P. 60, CEP: 13460-000, Nova Odessa, SP \\ ${ }^{3}$ Bolsista do CNPq
}

SUMMARY: This study characterized seven Pennisetum purpureum varieties, namely v. Anão, Bajra, Cameroon, Guaçu, Roxo, Taiwan A-144 and Uruckwami, through biochemical analyses, including protein, glucose and fructose contents, and polyacrylamide gel electrophoresis using the esterase system, by sampling $30,60,90,120$ and 150 day-old leaves. The number of nodes per stem and the percentage of bud emergence were also recorded. Variety Taiwan A-144 presented the highest number of nodes per stem and percentage of emerging buds. Protein concentration decreased gradually after 60 days for all varieties, except for Anāo. Variety Guaçu presented the highest level of glucose in $\mathbf{9 0}$ day-old plants, whereas Cameroon presented the highest levels at 120 and 150 days. The esterase band patterns changed with plant age for all varieties, showing a tendency to increase the number of bands with time. The best age for discriminating between esterase bands of $P$. purpureum varieties was at 120 days, when most variation could be observed.

Key Words: electrophoresis; reducing sugars; proteins; elephant grass; Pennisetum purpureum

\section{ANÁLISES BIOQUÍMICAS E ISOENZÍMICAS DE VARIEDADES DE CAPIM ELEFANTE Pennisetum purpureum (SCHUM)}

RESUMO: Foram analisadas sete variedades de P. purpureum, tais como: Anão, Bajra, Cameroon, Guaçu, Roxo, Taiwan A-144 e Uruckwami, através de testes bioquímicos determinando a concentração de proteinas, glicose e frutose, alem de observar, através de gel de eletroforese, as bandas de esterase. Os extratos protéicos foram preparados amostrando-se folhas com 30, 60, 90, 120 e 150 dias. Os números de n6s por colmo e a porcentagem de brotamento das gemas foram também avaliados. A variedade Taiwan A-144 apresentou o maior número de nós por colmo e porcentagem de brotamento das gemas. Com relaçāo a concentraçăo de proteinas, esta decresceu gradualmente apos 60 dias para todas as variedades, com exceçăo da Anão. A maior concentração de glicose foi apresentada pela variedade Guaçu aos 90 dias e pela Cameroon aos 120 e 150 dias. Os padrōes eletroforéticos da esterase se alteraram com a idade da planta para todas as variedades, mostrando tendéncia a aumentar o número de bandas com o tempo. A melhor idade para discriminar as variedades de capim elefante foi aos 120 dias, onde foi encontrada maior variação.

Descritores: eletroforese; aq̧ucares redutores; proteínas; capim elefante; Pennisetum purpureum

\section{INTRODUCTION}

Elephant grass (Pennisetum purpureum) is one of the most important grasses in the tropic and subtropic world regions (TCACENCO \& BOTREL, 1990). It is widely grown from sea level to $2,000 \mathrm{~m}$. altitude for fodder and for grazing. The grass is valued for its competitive ability and persistence, palatability and good herbage quality with high yields amounting to 300t. green matter/ha/y (BOGDAN, 1977 and PEREIRA, 1992).
Many ecotypes have been selected presenting great variation in their morphological, physiological and biochemical characteristics (PEREIRA, 1992). However, little is known about the real difference between these varieties, possibly because many have been introduced to different places with different names (TCACENCO, 1988), with no documentation of the original identities (TCACENCO \& BOTREL, 1990).

The discrimination of varieties is almost always a difficult task, due to phenotypical 
similarities that may exist among them, which could be overcome by biochemical analyses, such as protein and enzyme. The esterase system is the most conclusive isoenzyme system for varietal identification due to the complexity and quality of its patterns. The esterases are perhaps the most variable isoenzymes in plants and have been used to evaluate genetic affinities in several Gramineae (GOTTLIEB, 1981).

This paper reports on the content of soluble proteins, carbohydrates and esterase isoenzyme of seven Pennisetum purpureum varieties, some of them widely used in Brazil. Knowledge of these compounds may help to explain important aspects such as taxonomic identification and also the relationships with microorganisms.

\section{MATERIALS AND METHODS}

Plant Preparation: Elephant grass cuttings of seven varieties (Guaçu, Bajra, Anão, Cameroon, Roxo, Taiwan A-144 and Uruckwami) were planted in plastic bags containing fertilised soil, with two plants per bag and 10 bags (replications) per cultivar. This material was maintained in the greenhouse for 30 to 150 days. The percentage of bud emergence was recorded at $8,12,17,20$ and 22 days after planting. The number of nodes per stem was also recorded from 10 stems of each cultivar at 111 and 141 days after a uniformization cut in the field plots.

Sample preparation and chemical analysis: Samples from 30, 60, 90, 120 and 150 day-old leaves, marked on the second and third leaves from the apex of 30 day-old plants, were taken using two different extraction methods: $A$ ethanolic extraction; B - buffer extraction. The extractions were replicated three times.

A - Ethanolic extraction: Two grams of fresh cut small pieces of leaves without the midrib were dropped into $100 \mathrm{ml}$ boiling ethanol (80\%) for 5 minutes. After cooling, the extracted material was homogenised with a Waring Blender operated at full speed for $2 \mathrm{~min}$ and boiled in the same ethanol for a further $2 \mathrm{~min}$. The resulting material was filtered through Whatmann $n^{\circ} 42$ filter paper on a Buchner funnel. The suspension was evaporated in a porcelain capsule and recovered in water.
Glucose and fructose were analysed by the method of SOMOGYI (1945).

B - Buffer extraction: Three grams of fresh cut small pieces of leaves without the midrib, were homogenised in a Waring Blender operated at full speed for $2 \mathrm{~min}$ at $4^{\circ} \mathrm{C}$ with $30 \mathrm{ml}$ phosphate buffer $(0.1 \mathrm{M} \mathrm{pH} \mathrm{6.5),} \mathrm{containing} 0.85 \% \mathrm{NaCl}$, $0.25 \%$ mercaptoethanol, and $10 \%$ sucrose. Total protein was determined by the method of LOWRY et al. (1951) and isoenzymes were analysed by electrophoresis, using the esterase system.

Polyacrylamide gel electrophoresis: Electrophoresis was performed in horizontal polyacrylamide gels in the apparatus LKB multiphor. The gel for PAGE was prepared by the method of STEGEMANN et al. (1987) using $5 \%$ acrylamide in $0.125 \mathrm{M}$ tris-glycine buffer (pH 8.2). Sample solutions, standardised to 300 ug equivalent to $B S A / m l$, were loaded on the gel. The gels were run with constant miliamperage (mA). After electrophoresis, the gels were removed from the glass plates and incubated for $30-40 \mathrm{~min}$ at $37^{\circ} \mathrm{C}$ in $100 \mathrm{ml} 0.2 \mathrm{M}$ sodium phosphate buffer (pH 6.5) containing 50 mg Fast Blue RR salt, with the addition of $2 \mathrm{ml}$ $1 \%$ alpha-naphtyl acetate in acetone at $50 \%$.

The average relative mobility $(\mathrm{Rm})$ value of three gels was recorded for each extract. Gels were scanned in a densitometer and zymograms were prepared to compare the band patterns.

\section{RESULTS}

Number of nodes per stem: Cameroon presented the lowest number of nodes per stem and Taiwan A-144 the highest at 141 days after cutting (TABLE 1).

Percentage of bud emergence: The percentage of bud emergence was evaluated up to 22 days after planting. Variety Taiwan A-144 was the fastest to emerge, whereas Roxo, Guaçu and Uruckwami were slower to emerge, although Roxo showed a good recovery after the $12^{\text {th }}$ day (Figure 1).

Proteins: The protein contents gradually decreased after 60 days for all varieties, except for Anão, which showed the highest levels of 
TABLE 1 - Number of nodes per stem, 111 and 141 days after a uniformization cut.

\begin{tabular}{lll}
\hline Varieties & $111 \mathrm{~d}$ & $141 \mathrm{~d}$ \\
\hline Anão & 14.1 & $14.8^{*}$ \\
Bajra & 14.1 & $14.9^{*}$ \\
Cameroon & 10.5 & 10.7 \\
Guaçu & 13.3 & $14.2^{*}$ \\
Roxo & 14.9 & $14.9^{*}$ \\
Taiwan A-144 & 11.7 & $17.1^{*}$ \\
\hline
\end{tabular}

* Means are significantly different from the Cameroon ( $P<0.05 \%)$ according to the Student's t-test.

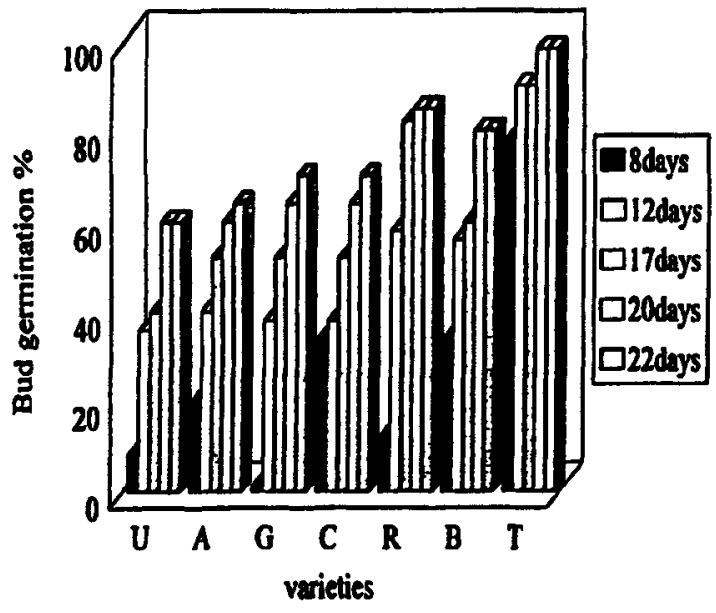

Figure 1 - Percentage of buds emerging at 8 , $12,17,20$ and 22 days after planting of Pennisetum purpureum varieties: U-Uruckwami, A-Anão, G-Guaçu, C-Cameroon, R-Roxo, B-Bajra, T-Taiwan A-144. Means between varieties and between ages are significantly different ( $P<0.05 \%)$, according to the Student's t-test.

protein at 90 and 120 day-old leaves (Figure 2). Variety Guaçu also presented a high level of protein at 90 days, decreasing gradually afterwards.

Reducing sugars: All varieties showed a low level of fructose up to 60 days, but increased after 90 days. Variety Roxo presented significantly higher levels of fructose than all the other varieties at 120 and 150 days (Figure 3).

Varieties Guaçu and Cameroon showed higher levels of glucose at $\mathbf{9 0}$ days, while an increase was observed for the other varieties at 120 day-old leaves. However, at 150 days the glucose concentration decreased for all varieties. Also, Cameroon presented the highest levels of glucose at 120 and 150 days, while Guaçu presented the highest level at 90 day-old leaves (Figure 4).

Electrophoresis: Esterase isoenzymes were assayed from 30 to $\mathbf{1 5 0}$ day-old leaves. Band patterns changed with leaf age for all varieties. The number of bands at 30 and 60 days were the same and showed slight differences among the varieties. The number of bands increased at 90 days and was more intense at 120 and 150 day-old leaves.

The number of esterase isoenzymes increased from 2 in the younger leaves to 3 in the older ones of variety Guaçu; and from 2 to 4 bands in the older leaves of Cameroon,

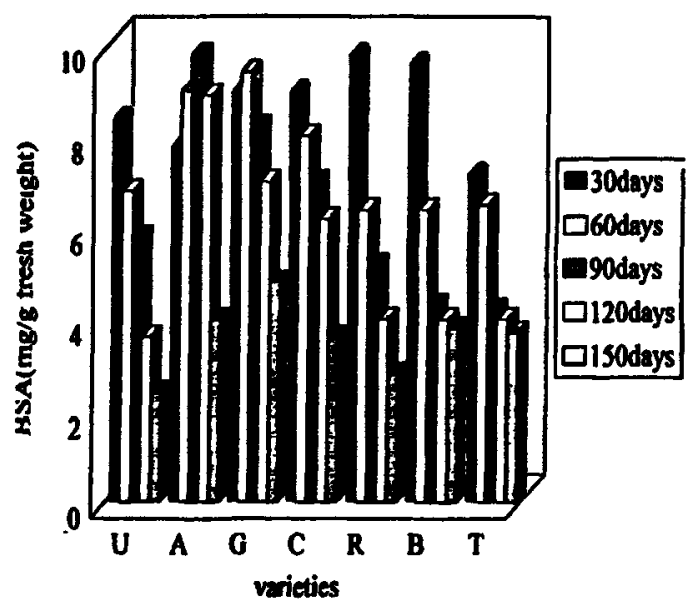

Figure 2 - Protein concentrations in the leaves of Pennisetum purpureum varieties: U-Uruckwami, A-Anão, G-Guaçu, C-Cameroon, R-Roxo, B-Bajra, T-Taiwan. Means between varieties and between leaf ages are significantly different $(P<0.05 \%)$, according to the Student's t-test. 


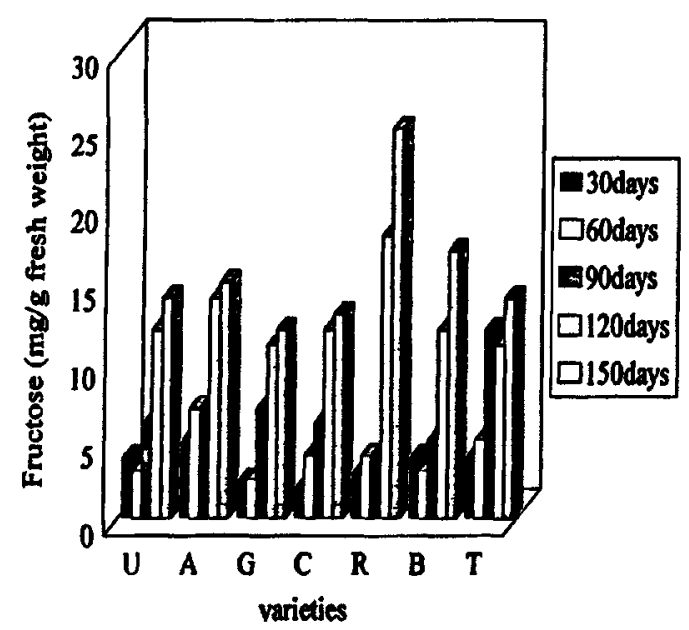

Figure 3 - Fructose concentrations in the leaves of Pennisetum purpureum varieties: U-Uruckwami, A-Anão, G-Guaçu, C-Cameron, R-roxo, BBajra, T-Taiwan A-144. Means between varieties and between leaf ages are significantly different $(P<0,05 \%)$, according to the Student's t-test.

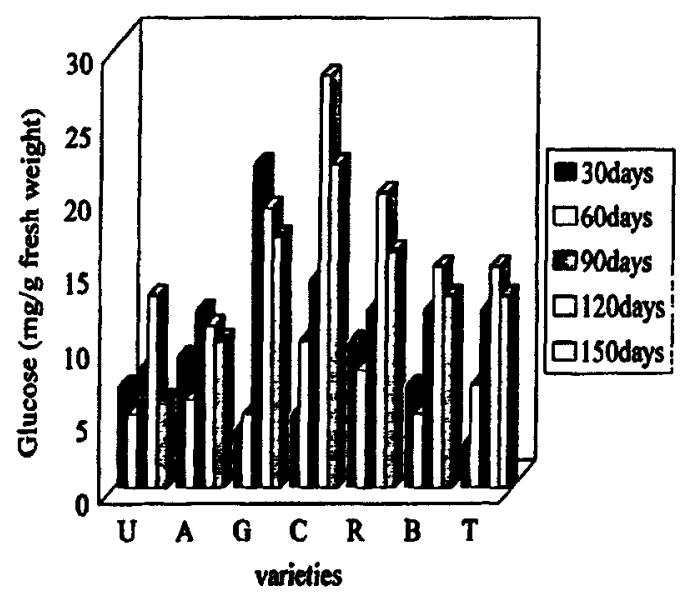

Figure 4-Glucose concentrations in the leaves of Pennisetum purpureum varieties: U-Uruckwami, A-Anão, G-Guaçu, C-Cameroon, R-Roxo, B-Bajra, T-Taiwan A-144. Means between varieties and between leaf ages are significantly different $(P<0,05 \%)$, according to the Student's t-test.
Uruckwami and Roxo. For variety Anão, the bands increased from 3 to 6 and for Bajra and Taiwan A-144 three bands appeared in all leaf ages, but with different relative mobilities.

All varieties presented a common band with $R m$ 3.8-4.0 at all leaf ages, while the other bands acted as markers for each cultivar. The best leaf age for $P$. purpureum variety discrimination, using the esterase system, was considered to be at $\mathbf{1 2 0}$ day-old leaves, when most variation was observed for each variety. At this stage, band pattern markers were observed for all varieties with relative mobilities of 2.8-3.0 for Guaçu ; 0.7-1.0, 1.5-1.9, 2.83.2 for Cameroon; 0.5-0.8, 1.6-2.0 for Uruckwami; 1.3-1.8 for Bajra; 1.4-1.8, 3.03.5 for Taiwan A-144; $0.5-0.9,1.4-1.6,1.9$ $2.1,2.4-2.6$ for Anão; and 0.8-1.0; 1.6-1.8 for Roxo. At 120 day-old leaves, some varieties also presented a common band, such as: Guaçu and Anão with $R m$ 0.5-0.9; Anão and Uruckwami with Rm 3.0-3.2; Roxo and Bajra with Rm 3.0-3.3 (Figure 5).

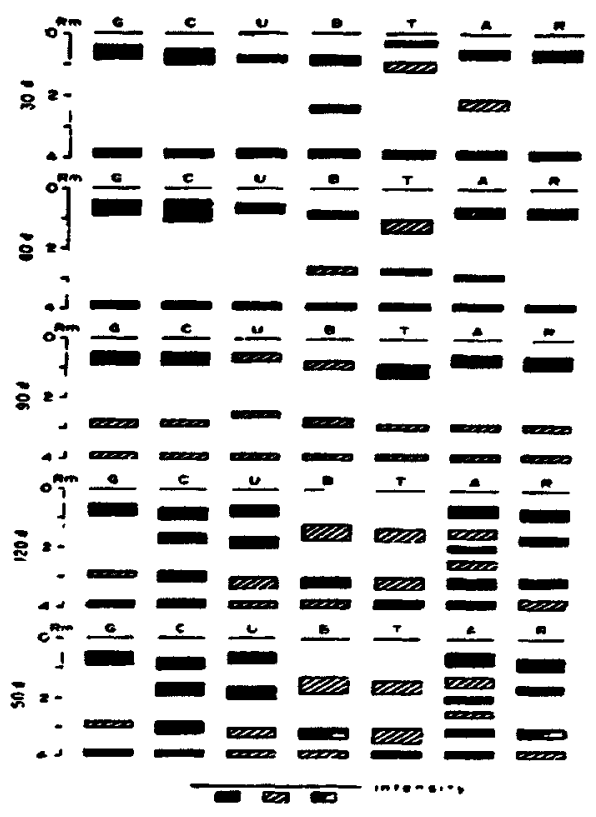

Figure 5 - Esterase zymograms of foliar extract of Pennisetum purpureum varieties: G-Guaçu, C-Cameroon, U-Uruckwami, B-Bajra, T-Taiwan A-144, A-Anão, R-Roxo, of 30, 60, 90,120 and 150 day-old leaves. 


\section{DISCUSSION}

Proteins and reducing sugars in leaves of Pennisetum purpureum were affected by the leaf age and variety. In the present study, protein content decreased with leaf age, while the reducing sugars, not in total, but with fructose and glucose separately, showed different results. Fructose increased while glucose decreased after 120 days for all varieties. These results are in accordance with SHREE \& REDDY (1986), who observed a decrease in protein with age in the varieties of Sorghum vulgare, although the reducing sugars, in total, were increased. These data indicate that biochemical substances are synthesized according to the necessity of the leaf age.

Many studies report that electrophoretic protein or enzyme patterns can be used for taxonomy or genetic studies (WILKINSON \& BEARD, 1972; HAYWARD \& MCADAM, 1977; HUSSEIN \& STEGEMANN, 1978; SHAH \& STEGEMANN, 1983; NICHOLSON el al., 1985; POVERENE et al., 1988; POVERENE \& CURVETTO, 1989). The isoenzymatic systems are considered to be the most polymorphic in studies of intervarietal variability of numerous species (POVERENE et al., 1988).

Alterations in enzymatic and also biochemical substances in the older leaves was observed in this study, and this is primordial for the padronization in the selection of the leaf age for variety characterization analyses.

Under our experimental conditions, electrophoresis of esterase indicated that some isoenzymes were peculiar to young leaves (3060 days), and others to older leaves $(90,120$ and 150 days). This is in accordance with JOHNSON (1974) and STEWARD et al. (1965), who observed the changes in metabolism during plant development that are closely related to different patterns of proteins and isoenzymes of various tissues, as the production of some proteins or enzymes is considered to be the result of differential gene action. In the present study, a better resolution in electrophoresis was obtained in adult leaves, demonstrating the existence of alteration in the isoenzymatic patterns during plant development.

In the zymograms, a common band was observed for all Pennisetum purpureum varieties, while the other bands acted as markers for each variety. The marker bands with different mobilities characterized the different varieties.

In the morphological studies, variety Taiwan A-144 presented the highest number of nodes per stem and was also the fastest to emerge. The results are in accordance with ALCÂNTARA et al. (1980), who observed the highest dry matter production/ha/year for that variety. However, that variety presented in our study the lowest concentration of proteins, being surpassed by all the other varieties.

The results obtained in this study demonstrated that the isoenzymatic characterization is an important complement to morphological and biochemical data for differentiating varieties. Further analyses are under way with other Pennisetum purpureum varieties in order to compare their esterase band patterns as an aid to the morphological and agronomic evaluations.

\section{REFERENCES}

AlCÂNTARA, P.B.; ALCÂNTARA, V.B.G.; ALMEIDA, J.E. Estudo de vinte e cinco prováveis variedades de capim-elefante (Pennisetum purpureum Schum.). Boletim de Indústria Animal, v.37, p.279-302, 1980.

BOGDAN, A.V. Tropical pasture and fodder plants (grasses and legumes). New York: Longman, 1977. 475p. (Tropical Agricultural Series)

GOTTLIEB, L.D. Electrophoreic evidence and plant populations. Progress in Phytochemistry, v.7, p.146,1981 .

HAYWARD, M.D.; McADAM, N.J. Isozyme polymorphism as a measure of distinctiveness and stability in cultivars of Lolium perenne. Zeitschrift fur Pflanzenzuchtung, v.79, p.59-68, 1977.

HUSSEIN, K.R.F.; STEGEMANN, H. Comparison of proteins from wheat kernels by various electrophoretic methods in polyacrylamide. Zeitschrift fur Acker und Pflanzenbau, v.146, p.68-78, 1978.

JOHNSON, G.B. Enzyme polymorphism and metabolism. Science, v.184, p.28-37, 1974.

LOWRY, O.H.; ROSENBROUGH,N.J.; FARR, A.L.; RANDALL, R.J. Protein measurement with the Folin phenol reagent. Journal of Biological Chemistry, v.193, p.265-275, 1951. 
NICHOLSON, C.H.L.; CONLAN, L.L.; COOK, S.J. Cenchrus pasture species and cultivar idemification using morphological and biochemical tecniques. Seed Science and Technology, v.13, p.243-255, 1985.

PEREIRA, A.V. Eacolha de variedades de capim elefante. In: SMPÓSIO SOBRE MANEJO DE PASTAGENS, Piracicaba, 1992,. Anais... Piracicaba, 1992. p. 47-62.

POVERENE, M.M.; RENZO, M.A.; CURVETTO, N.R. Diferenciación de cultivares de pasto llorón Eragrostis curvula (Schrad.) Nees, mediante electroforesis de isoenzimas en Argentina. Turrialba, v.38, p.173-178, 1988.

POVERENE, M.M.; CURVETTO, N.R. Esterase isozyme variation in the Eragrostis curvula complex (Poaceae). Plant Systematics and Evolution, v.166, p.173-181, 1989.

SHAH, A.; STEGEMANN, H. Proteins of Jojoba beans (Simmondsia chinensis), extraction and characterization by electrophoresis. Zeitschrift fur Acker und Pflanzembau, v.152, p.39-47, 1983.

SHREE, M.P.; REDDY, C.N. Effect of helminthosporiose infection on certain biochemical constituents in the resistant and susceptible varieties of Sorghum. Indion Journal of Plant Pathology, v.4, p.46-52, 1986.

SOMOGYI, M. A new reagent for the determination of sugars. Journal of Biological Chemistry, v.160, p.61-68, 1945.
STEGEMANN, H.; BURGERMEISTER, W.; SHAH, A.A. Gel-elektrophorese und isoelektrischefokussierung.BBA, Braunschweis, 1987.

STEWARD, F.C.; RYNDON, R.F.; BARBER, J.T. Acrylamide gel electrophoresis of soluble plant proteins study on pea seedlings in relation to development. American Jonmal of Botany, v.52, p.155-164, 1965.

TCACENCO, F.A. Seleçío de caracteres para a classificaça de tres cultivares de capim elefante. Pasturas Tropicales, v.10, p.14-19, 1988.

TCACENCO, F.A.; BOTREL, M.A. Identificaçăo e avaliação de acessos e cultivares de capim elefante. In: REUNIÃO ANUAL DA SOCIEDADE BRASILEIRA DE ZOOTECNIA, Coronel Pacheco, 1990. Anais... Coronel Pacheco: Sociedade Brasileira de Zootecnia, 1990. p. 122.

WILKINSON, J.F.; BEARD, J.B. Electrophoretic identification of cultivars. Crop Science, v.12, p.833-834, 1972.

Recebido para publicação em 17.07 .95

Aceito para publicação em 02.08 .95 